\title{
Review of floral polymorphism in chía (Salvia hispanica L.): Modified cause
}

\section{Revisión del polimorfismo floral en chía (Salvia hispanica L.): Causa modificada}

CALDERÓN-RUIZ, Alberto†*, VARGAS-ESPINOZA, Everardo, GAYTÁN- RUELAS, Marina y MARTÍNEZ-CAMACHO, Adriana Paola

\author{
Universidad Tecnológica del Suroeste de Guanajuato, Carretera Valle-Huanímaro km. 1.2, Valle de Santiago, Guanajuato, \\ 38400. México
}

ID $1^{\text {st }}$ Author: Alberto, Calderón-Ruiz / ORC ID: 0000-0002-1721-2953, CVU CONACYT ID: 167136

ID $1^{\text {st }}$ Coauthor: Everardo, Vargas-Espinoza / ORC ID: 0000-0002-1238-7981, CVU CONACYT ID: 384590

ID $2^{\text {nd }}$ Coauthor: Marina, Gaytán- Ruelas / ORC ID: 0000-0002-9714-7628, CVU CONACYT ID: 343244

ID $3^{\text {rd }}$ Coauthor: Adriana Paola, Martínez-Camacho / ORC ID 0000-0003-1970-4633, CVU CONACYT ID: 714204

DOI: $10.35429 /$ JNAS.2020.20.7.14.20

Received March 21, 2020; Accepted June 30, 2020

\begin{abstract}
This article reviews the current state of knowledge about the color of the flower of the chia (Salvia hispanica L.) plant because it presents different colors, within a population that was the basis for the generation of five internationally marketed varieties. After a historical review of the most influential studies on floral color polymorphism, the different types of pigments involved and other anthropogenic manipulations such as the application of ionizing radiation that may affect the final color of flowers are analyzed; the latter is involved in the current polymorphism of this species. Although there is a great diversity of types of floral polymorphism, those related to the loss of anthocyanic pigments are the most frequent in wild species. On the contrary, in chia it is the opposite, so far there are no study reports on chia cultivation that support this relationship, in this article we propose a possible hypothesis in relation to a genetic mechanism that is the modified cause of the floral polymorphism it presents.
\end{abstract}

Polymorphism, Ionizing radiation, Salvia hispanica L.

\begin{abstract}
Resumen
En este trabajo se revisa el estado actual del conocimiento sobre la coloración de la flor de la planta de chía (Salvia hispanica L.) dado que presenta diferentes coloraciones, dentro de una población que fue base para la generación de cinco variedades comercializadas internacionalmente. Tras un repaso histórico de los estudios más influyentes sobre polimorfismo en el color floral, se analizan los diferentes tipos de pigmentos involucrados y otras manipulaciones antropogénicas como la aplicación de radiación ionizantes que pueden afectar al color final de las flores; este último involucrado en el polimorfismo actual de la chía. Aunque existe una gran diversidad de tipos de polimorfismo floral, los relacionados con la pérdida de pigmentos antociánicos son los más frecuentes en especies silvestres. Por lo contrario, en la chía es lo inverso, hasta el momento no existen reportes de estudio en el cultivo de la chía que sustente esta relación, en este trabajo se propone una posible hipótesis en relación con un mecanismo genético que sea la causa modificada del polimorfismo floral que presenta.
\end{abstract}

Polimorfismo, Mutación por radiación, Salvia hispanica $\mathrm{L}$.

Citacion: CALDERÓN-RUIZ, Alberto, VARGAS-ESPINOZA, Everardo, GAYTÁN- RUELAS, Marina y MARTÍNEZCAMACHO, Adriana Paola. Review of floral polymorphism in chía (Salvia hispanica L.): Modified cause. Journal of Natural and Agricultural Sciences. 2020, 7-20: 14-20

\footnotetext{
*Correspondence to Author (acalderonr@utsoe.edu.mx)

$\dagger$ Researcher contributing first author.
} 


\section{Introduction}

Studying the structures of flowers has fascinated many botanists such as Lineo, who used structures to classify different species, and evolutionary biologists such as Ronald Fisher who laid the mathematical foundations for the study of their evolution (Barrett, 2002). On the other hand, the color of flowers has been a subject of study that has fascinated many; For example: Aristotle, Mendel, Batenson among others, currently continues to generate a large amount of bibliography, being a model system that allows the depth of the study of ecological and evolutionary processes.

For example, flower color constitutes a simple model for studying the adaptation of plants to new pollinators (Hoballah et al., 2007). and the knowledge of the genetic basis that determine floral color has allowed integrating molecular genetics with evolutionary ecology (Álvarez-Buylla et al., 2017). The floral color polymorphism is the discrete and qualitative variations of floral color between individuals of the same species both at the population level and between populations (Narbona, 2014).

\section{Color in flowers}

Although Gregor Mendel (1866) is considered the father of genetics, for his contribution to his famous laws of inheritance. A Mendel observation that is probably the least known was that the absence of pigments in the white petals was associated with the lack of pigmentation in the seed coat and in the leaf axilla (Ellis et al. 2011; Reid and Ross 2011). In 1916, the book "Anthocyanin pigments in plants" by Muriel Whledale was published, where numerous cases of polymorphisms based on anthocyanin compounds were documented and the patterns of variation and their inheritance were analyzed in detail.

Perhaps one of the most studied polymorphism cases is that of Linanthus parryae, this species has an interesting distribution pattern of floral color morphotypes, since there are monomorphic populations and dimorphic populations, with white and blue individuals (Epling and Dobzhansky, 1942).
Pigments are chemical compounds that, when light falls on them, absorb certain wavelengths and reflect the rest (which is what we perceive as color). Humans detect colors with wavelengths between 380 and $730 \mathrm{~nm}$ (nanometers); however, pollinators, mainly insects and birds, also perceive shorter "ultraviolet" wavelengths (Kelber et al., 2003).

Pigments in plants are classified into four large groups: chlorophylls, carotenoids, flavonoids and betalains. Chlorophylls, which provide a green color, are a constitutive part of vegetative tissues and sepals. That rarely accumulate in the petals or tepals, although there are exceptions such as in the Orchidaceae family (Vignolini et al., 2012). ). Carotenoids are isoprenoids and generate the colors yellow, orange and red in some flowers (Lee, 2007). Flavonoids are the pigments that provide the most color diversity to flowers (Lee 2007; Miller et al. 2011). Among them, anthocyanins are the most important flavonoids and provide an orange, red, blue, pink, purple color, and in some cases almost black (Shikazono et al. 2008). The white color in the petals generally responds to the lack of pigments; As there are no pigments that absorb a part of the light spectrum, it is completely reflected. Only one type of pigment accumulates in the petals (Glover 2007; Lee 2007).

Not all color polymorphisms are equally frequent or come from the evolution or coevolution that has been given to cultivated species. In wild species, more diversity of polymorphisms can be found; For example, we can cite various cases of variation in the color of the flowers, for example in the Lycoris longituba species, the color of the petals of its leaves can vary purple, red, orange-yellow (He et al. 2011). In Ursinia calenduliflora we can find orange, red and black, although in this one, it is due to the presence of macules on the petals. (From Jager and Ellis, 2014). The pink to white Mimulus lewisii species (Wu et al., 2013). and Parrya nudicaulis purple to white (Dick et al. 2011). This may possibly be related to what can be found in S. hispanica L. On the other hand, there are other types of polymorphism that affect the uniformity of the color of the petals. Thus, there may be a variation in the presence or absence of macules or venation on the petals. 


\section{Mutagenesis in plant breeding.}

The discovery of X-rays, radioactivity and the handling of radioactive elements, gave rise to the deliberate induction of mutations in the genetic structure in plants. These mutations have generated a number of successful and promising varieties.In 2017, more than 700 varieties were registered in the database of mutant varieties of the joint agency of the Food and Agriculture Organization of the United Nations, and the International Atomic Energy Agency. Among the main reported genera, Chrysanthemum, Rosa, Dahlia and Alstroemeria stand out, with 283, 67, 35 and 35 registered varieties, respectively (Hernández-Muñoz, 2020).

It should be noted that the demand for novel varieties continues to grow and implies a challenge for plant breeders. One of the techniques that dramatically induces mutagenesis in plants is ionic irradiation. When plant material is irradiated, due to its characteristics and its high penetration range, it can cause changes in important molecules such as deoxyribonucleic acid (DNA), which translates into variation in plant species.

\section{Chia and its appearance}

The research on chia is recent compared to other crops that are the basis of food, it began in the 90 's, the chemical composition of the seed being the main focus of research centers, in this sense science began to determine the stability of the oil production present in the grain and its composition in general; Thanks to this, today chia is considered one of the most important sources of polyunsaturated fatty acids (AGPINs or PUFAs in English) Omegas 3 and 6, proteins, oil and fiber (Baginsky et al., 2016; Ullah et al. ., 2017) .The consumption of fatty acids (Omega 3 ) favors the deformation of erythrocytes and the decrease of viscosity in the blood, this effect provides greater oxygenation to the tissues, as well as reduces cholesterol and triglycerides in blood also reduces blood pressure, which is associated with cardiovascular diseases (Coelho and Salas, 2014). Chia seed contains between 9 and $23 \%$ protein, 26 to $41 \%$ non-fibrous carbohydrates and 30 to $33 \%$ of the total weight of the seed is oil. That is why it is considered as a functional food and hence its importance today (Oliveros and Paredes, 2013; Olivos-Lugo et al., 2010).
Regarding the floral characteristics, few studies speak of the relationship of the flowers in relation to the color of the seeds. Since the importance falls on the color of the seed, which is currently an influence on commercialization. At present, only five commercial registered varieties of chia are reported (Sosa et al., 2016), the first developed in the United States (Hearthland, 2016; Jamboonsri et al., 2012), being available to the public in white and black seed, being the Hearthland company that has the breeder's right (Hildebrand et al., 2016). The three remaining genotypes were registered in Argentina, which are named Sahi Alba 911, Sahi Alba 912 and Sahi Alba 914 (Bochicchio et al., 2015). Currently Mexico already has a highyield line, being the first variety of white chia (Rovati et al., 2012). Similarly, in 2019 the patent "Patent No .: US20190183084A1 chia variety designated rehnborg" is obtained (SosaBaldivia et al 2019).

It is necessary to mention that to generate the five previous varieties of chia; A variety of Mexican called "Pinta" that comes from the state of Jalisco, specifically from the Acátic municipality, was used as a genetic source. Which is a mixture of black and white seeds in a 9: 1 ratio (Coates and Ayerza, 1998; Jamboonsri et al., 2012; Sosa et al., 2016).

\section{Methodology}

\section{Project location and plant material}

In 2017 , the chia variety "pinta" was established in the experimental fields of the Sustainable and Protected Agriculture career of the Technological University of the Southwest of Guanajuato, in Valle de Santiago. In which floral polymorphism was identified in the population, they were selected and protected.

The protected seeds were established in 2019, in the same fields of the University. Showing the same polymorphism. In the literature, the existence of a great diversity of types of floral polymorphism is reported, most of them are related to the loss of anthocyanin pigments and are the most frequent in wild species, which is why it is striking in the cultivation of chia. The variety "pinta" is cultivated in different parts of the country. 


\section{Results and discussions}

The polymorphism presented in the evaluated population of the most representative chia "Pinta" was the following:

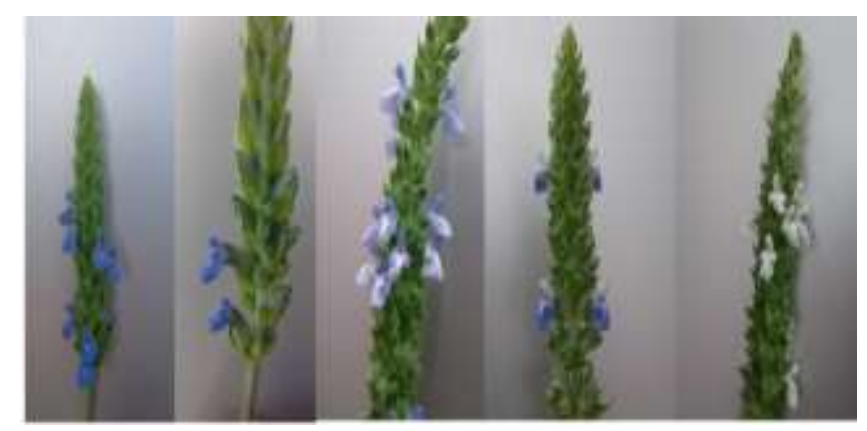

Figure 1 Floral polymorphism in chía "Pinta"

As can be seen, the variation of these colors in chia is diverse, it was reviewed in the literature, with the possibility of finding an explanation for this variation presented by the "Pinta" population, and its possible anthropogenic management, the following was found:

\section{The Mexican chia and its appearance in the world}

The integration of chia into modern agriculture began in 1991 with the "Western Argentina Regional Project". The results obtained from this project were so impressive that the implementation of the technology generated led to the area cultivated with chia going from 500 hectares in 1994 to 370,000 hectares in 2014 (Orozco. 1993, Weber et al. 1991). But as the interest in the cultivation of chia arises, perhaps the base report in the bibliographic review carried out is the work is by Orozco De Rosas (1993), who in his thesis reports that the seeds used in his work were wild chías, the Which are obtained from generation to generation and from his account he mentions that for years this plant is cultivated in the town of Acatic.

There is little information regarding what happened in this period; but the history of chia was written a few years ago by Ricardo Ayerza and Wayne Coates (2006) responsible for the "Western Argentina Regional Project", the two foreign researchers (Canadian and Argentine nationals, respectively) who have conducted the most research on this culture.
Generating five varieties registered internationally and which the first place in the world production of this crop is Argentina; while Mexico is in third place (Peperkamp, 2015).

What is striking about the local varieties, there was a record, it was improved or because there is only a record of this plant outside of Mexico, since it is considered a center of origin in Mexico, are some of the questions that we can generate.

There is a report of what happened and a possible theory that is in relation to the Mexican chia and the success of the project "Western Argentina Regional Project" recovered from the website:

https://web.archive.org/web/20140321145146/h ttp : //chiablanca.com.mx: 80 / investigation.

According to the information prepared by G. Orozco De Rosas, he mentions the following: "Acatic, Jalisco. located in western Mexico, where the natives were of Nahua origin, they conserved the cultivation and it has been the center of development of this variety until today. Not only has it been cultivated since time immemorial, but all the technology for producing, harvesting and processing the grain for Central, South America and Australia was generated here. All the varieties of chia that are currently planted in the world have their origin in Acatic, Jalisco since the native variety of Acatic is a mixture of $90 \%$ black seeds and approximately $10 \%$ white seeds.

Due to its characteristics of Precocity and performance adapted to the agroecological conditions of Acatic, where the plant produces the highest amount of Omega 3 fatty acids and antioxidants. Pioneers in research and development of this crop since 1987, currently the result has been that CHIABLANCA SC DE $\mathrm{RL}$, a family cooperative, has the largest collection of Agronomic research on this important crop".

On the same page, Orozco De Rosas describes that this crop has been planted since time immemorial. Regarding the maternal relatives, there is no exact date of the initiation of his cultivation, only the reference of his greatgreat-grandparents. 
He initiates experimental work on the selection of lines of plants with contrasting characteristics, varieties with black seeds, white seeds, blue pubescence, pigmentation on the stem, and wild species with open calyx. On the other hand, in search of precocious silvers that were not affected by the lack of humidity and frost, he decided to look for diversity. With the application of X-rays to the seeds, as a result of that work in 1991, he already had several pure lines of plants of: white seeds, black seeds, light blue flowers. strong blue flower (almost purple), blue pubescence, pigmentation on the stem.

Although, this is clear that on the one hand C. Orozco de Rosas is a key element in the generation of genetic diversity of this species of chia and perhaps the use of X-rays is the answer to the polymorphism of chia. Since this happened before the entire report from the great project "Western Argentina Regional Project" was released. The question is why other researchers from other countries made it known and not the Mexicans.

There is a large number of scientific articles and studies in magazines, books and web pages, and according to countless authors, on floral polymorphism and its possible causes, which help us document and compare them with each other, and thus be able to generate An overview of the floral polymorphism that occurs in the flowers of various species and botanical families, using this as a reference to propose a possible cause of the floral polymorphism in chia (S. hispanica L.), we know that the existence of the white chia that has white flowers and black chia that has blue-purple flowers that are the characteristics of internationally registered chias.

In relation to the literature, in the case of plants with white flowers they produce white seeds and the plants with blue or colored flowers produce black seeds, so it differs from what Orosco de Rosas mentions, it should be noted that perhaps this morphology that It occurs in the flowers in chia can prompt a more specific research topic, for example, the study of the plant-insect relationship. One answer to what may have happened in this culture of $\mathrm{S}$. hispanica L. is to compare it with the work of Hellens et al. (2010), which identified the genes $\mathrm{A}$ and $\mathrm{A} 2$ of the pea.
A is the factor that determines anthocyanin pigmentation in pea that was used by Gregor Mendel 160 years ago in his study of heredity. Gene A encodes a transcription factor bHLH. The white flower mutant allele most likely used by Mendel is a simple transition from Guanine to Adenine at a splice donor site leading to a mis-spliced mRNA with a premature codon, and a rare second mutant allele has been identified. The A2 gene encodes a WD40 protein that is part of an evolutionarily conserved regulatory complex.

\section{Conclusions}

The flower color polymorphism of chia (Salvia hispanica L.) with respect to its generation of diversity has been documented by the use of Xrays, which gives us an overview of the possible cause of floral polymorphism in this species. Compared to the work of the pea, it can be investigated that possibly a gene that controls color in flowers may have been silenced or activated with the application of X-rays, hence the difference in color in the petals of the flowers in Chia, remains to be verified. and there is a high probability that the flower polymorphism in chia is due to anthropogenic modification.

\section{References}

Álvarez-Buylla, Elena R., Garay-Arroyo, Adriana, García-Ponce de León, Berenice, Sánchez, María de la Paz, González-Ortega, Emmanuel, Dávila-Velderrain, José, MartínezGarcía, Juan Carlos, \& Piñeyro-Nelson, Alma. (2017). La Ecología Evolutiva del Desarrollo en México. Revista mexicana de biodiversidad, 88(Supl. dic), 14-26.

Ayerza y Coates. (2006). En su: Chía, redescubriendo un olvidado alimento de los aztecas. In El renacimiento de la chía (Del Nuevo, p. 205). Buenos Aires, Argentina.

Baginsky, C., Arenas, J., Escobar, H., Garrido, M., Valero, N., Tello, D., ... Silva, H. (2016). Growth and yield of chia (Salvia hispanica L.) in the Mediterranean and desert climates of Chile. Chilean Journal of Agricultural Research, 76(3), 255-264.

Barrett, S. C. H. 2002. The evolution of plant sexual diversity. Nature Reviews Genetics. 3(4): 274-284. 
Bochicchio, R., Philips, T., Lovelli, S., Labella, R., Galgano, F., Di Marisco, A., ... Amato, M. (2015). Innovative Crop Productions for Healthy Food: The Case of Chia (Salvia hispanica L.). In The Sustainability of Agro-Food and Natural Resource Systems in the Mediterranean Basin (pp. 29-45).

Coates, W., and Ayerza, R. (1998). Commercial production of chia in Northwestern Argentina. Journal of the American Oil Chemists' Society, 75(10), 1417-1420. https://doi.org/10.1007/s11746-998-0192-7

Coelho, M. S., y Salas, M. M. de las M. (2014). Revisão: Composição química, propriedades funcionais e aplicações tecnológicas da semente de chia ( Salvia hispanica L ) em alimentos Review: Chemical composition, functional properties and technological applications. Brazilian Journal of Food Technology, 17(4),259-268.

De Jager, M.L., Ellis, A.G. 2014. Floral polymorphism and the fitness implications of attracting pollinating and florivorous insects. Annals of Botany. 113:213-222

Dick, C.A., Buenrostro, J., Butler, T., Carlson, M.L., Kliebenstein, D.J., Whit-tall, J.B. 2011. Arctic mustard flower color polymorphism controlled by petal-specific downregulation at the threshold of the anthocyanin biosynthetic pathway. PLoS ONE 6:e18230

Ellis, T.H., Hofer, J.M., Timmerman-Vaughan, G.M., Coyne, C.J., Hellens, R.P. 2011. Mendel, 150 years on. Trends in Plant Science 16:590596.

Epling, C., Dobzhansky, T. 1942. Genetics of natural populations. VI. Micro-geographic races in Linanthus parryae. Genetics 27:317-332.

Glover , B.J., Martin, C. 1998. The role of petal cell shape and pigmentation in pollination success in Antirrhinum majus. Heredity 80:778-784

He, Q., Shen, Y., Wang, M., Huang, M., Yang, R., Zhu, S., Wang, L., Xu, Y.,Wu, R. 2011. Natural variation in petal color in Lycoris longituba revealed by anthocyanin components. PLOS ONE 6:e22098.
Hearthland. (2016). Chia Grown, harvested and processed in the USA for total identity preservation. http://www.heartlandchia.com/

Hellens RP, Moreau C, Lin-Wang K, Schwinn KE, Thomson SJ, Fiers MWEJ, et al. (2010) Identificación del carácter de la flor blanca de Mendel. PLoS ONE 5 (10): e13230.

Hernández-Muñoz, Selene, Pedraza-Santos, Martha Elena, López, Pedro Antonio, GómezSanabria, Juan Manuel, \& Morales-García, José Luciano. (2019). La mutagénesis en el mejoramiento de plantas ornamentales. Revista Chapingo. Serie horticultura, 25(3), 151-167.

Hoballah, M.E., Gübitz, T., Stuurman, J., Broger, L., Barone, M., Mandel, T., Dell'Olivo, A., Arnold, M., Kuhlemeier, C. 2007. Single gene-mediated shift in pollinator attraction in Petunia. The Plant Cell19:779-790.

Jamboonsri, W., Phillips, T. D., Geneve, R. L., Cahill, J. P., and Hildebrand, D. F. (2012). Extending the range of an ancient crop, Salvia hispanica L.-a new w3 source. Genetic Resources and Crop Evolution, 59(2), 171-178.

Kelber, A., Vorobyev, M., Osorio, D. 2003. Animal colour vision-behavioural tests and physiological concepts. Biological Reviews 78:81-118.

Lee, D.W. 2007. Nature's palette. University of Chicago Press, London, UK.

Mendel, G. 1866. Versuche über Plflanzenhybriden. Lectura del 8 de febrero y 8 de marzo en la Sociedad de Historia Natural de Brünn. Traduccion al inglés en http://www.mendelweb.org/MWarchive.html.

Miller, R., Owens, S. J., Rørslett, B. 2011. Plants and colour: Flowers and pollination. Optics and Laser Technology 43:282-294.

Narbona, E., Buide, M. L., Casimiro-Soriguer, I., \& Del Valle, J. C. (2014). Polimorfismos de color floral: causas e implicaciones evolutivas. Revista Ecosistemas, 23(3), 36-47.

Oliveros, S. M. R., \&amp; Paredes, L. O. (2013). Isolation and characterization of proteins from chia seeds (Salvia hispanica L.). Journal of Agricultural and Food Chemistry, 61(1), 193201.

CALDERÓN-RUIZ, Alberto, VARGAS-ESPINOZA, Everardo GAYTÁN- RUELAS, Marina y MARTÍNEZ-CAMACHO, Adriana Paola. Review of floral polymorphism in chía (Salvia hispanica L.): Modified cause. Journal of Natural and Agricultural Sciences. 2020 
Olivos-Lugo B.L, Valdivia-López M.Á. and Tecante A. (2010). Thermal and Physicochemical Properties and Nutritional Value of the Protein Fraction of Mexican Chia Seed (Salvia hispanica L.). Food Science and Technology International, 16(1), 89-96.

Orozco DRG, 1993. Evaluación de malezas para el control de malezas en chía (Salvia hispanica L.) en condiciones de temporal en Acatic, Jalisco. Tesis de Ingeniero Agrónomo. Universidad de Guadalajara. Zapopan, Jalisco, México. 81 p.

Reid, J.B., Ross, J.J. 2011. Mendel's genes: Toward a full molecular characterization. Genetics 189:3-10.

Rovati, A., Escobar, E., y Prado, C. (2009). Metodología alternativa para evaluar la calidad de la semilla de chía (Salvia hispanica L.) en Tucumán, R. Argentina. EEAOC-Avance Agroindustrial, 33, 44-46.

Shikazono, N., Yokota, Y., Kitamura, S., Suzuki, C., Watanabe, H., Tano, S., \& Tanaka, A. (2003). Mutation rate and novel tt mutants of Arabidopsis thaliana induced by carbon ions. Genetics, 163(4), 1449-1455.

Sosa, A., Ruiz, G., Rana, J., Gordillo, G., West, H., and Sharma, M. (2016). Chia Crop (Salvia hispanica L .): its History and Importance as a Source of Polyunsaturated Fatty Acids Omega-3 Around the wor. Crop Research and Fertilizers Review Open, 1, 1-9.

Sosa, B. A., Ruiz, ibarra G., Miranda, C., Gordillo, S., Westh, H., and Mendoza, G. (2016 b). Agronomic and physiological parameters related to seed yield of white chia (Salvia hispanica L.). Acta Fitogenetica. Sociedad Mexicana de Fitogénetica A.C, p. Vol.3.

Sosa-Baldivia Anacleto, Gordillo-Sobrino Gerardo Víctor. (2019) Chia variety designated rehnborg.https://patents.google.com/patent/US2 0190183084A1/en?q=salvia+hispanica\&invent or=SosaBaldivia\&oq=salvia + hispanica ++ SosaBaldivia+

Ullah, R., Nadeem, M., \& Imran, M. (2017). Omega-3 fatty acids and oxidative stability of ice cream supplemented with olein fraction of chia (Salvia hispanica L.) oil. Lipids in Health and Disease, 16(1), 34.
Vignolini, S., Davey, M.P., Bateman, R.M., Rudall, P.J., Moyroud, E., Tratt, J., Malmgren, S., Steiner U., Glover, B.J. 2012. The mirror crack'd: both pigment and structure contribute to the glossy blue appearance of the mirror orchid, Ophrys speculum. New Phytologist 196:10381047.

Weber WC, Gentry SH, Kolhepp AE, McCrohan RP. 1991. The nutritional and chemical evaluation of chia seeds. Journal of Ecology of Food Nutrition. 26: 119-125.

Wu, C.A., Streisfeld, M.A., Nutter, L.I., Cross, K.A. 2013. The genetic basis of a rare flower color polymorphism in Mimulus lewisii provides insight into the repeatability of evolution. PLos ONE 8:e81173

Wu, R. 2011. Natural variation in petal color in Lycoris longituba revealed by anthocyanin components. PLOS ONE 6:e22098. 